\title{
EL SUPREMO RECURSO DEL PATRIARCA
}

\section{Los dictadores de novela según el modelo hacendario de gobierno}

\author{
Carlos Germán van der Linde \\ Universidad de La Salle
}

\section{Resumen}

Carlos Fuentes, en una obra de 1969 titulada La nueva novela hispanoamericana, anticipa el trabajo de Ángel Rama sobre el dictador como arquetipo latinoamericano, el de Irlemar Chiampi sobre el realismo maravilloso y las novelas de Carpentier, Roa Bastos y García Márquez. En el primer capítulo de esta obra, Fuentes enuncia dos arquetipos propiamente hispanoamericanos: el primero es el de la "naturaleza devoradora", que se encuentra en los orígenes mismos del sujeto híbrido hispano-americano y en el desarrollo de un sincretismo histórico. Este mismo legado cultural da cuenta del surgimiento del segundo arquetipo: "el dictador a escala nacional o regional", puesto que los efectos colaterales de la independencia superpusieron a la antigua dominación un nuevo despotismo que en la mayoría de casos fue ejercido por militares o por oligarquías nativas. Este último arquetipo será estudiado en El otoño del patriarca, de Gabriel García Márquez, como un índice de premodernidad gubernamental.

\section{Palabras clave}

Carlos Fuentes, Gabriel García Marquez, dictador, Latinoamérica.

\begin{abstract}
Carlos Fuentes, in a 1996 work entitled La nueva novela hispanoamericana, anticipates the work of Ángel Rama about the dictator as Latin American archetype, the work of Irlemar Chiampi about the wonderful realism and the novels by Carpentier, Roa Bastos and García Márquez. In the first chapter of this work, Fuentes states two typical Latin American archetypes: The first one is that of the "all-consuming nature" that is found in the origins of the Spanish-American hybrid subject and in the development of a historical syncretism. This same cultural legacy gives rise to the second archetype: "the dictator at local or domestic level", since the collateral effects of the independence superimposed to the old domination a new despotism that in most cases was promoted by the military or by the native oligarchies. This last archetype will be studied in El otoño del patriarca by Gabriel García Márquez as a sign of government premodernity.
\end{abstract}




\title{
Key words
}

\author{
Carlos Fuentes, Gabriel García Márquez, dictator, Latin America.
}

\section{La novela del dictador}

Desde el primer capítulo de La nueva novela hispanoamericana (1969) ${ }^{1}$, Carlos Fuentes postula dos arquetipos ideológicos propiamente hispanoamericanos, los cuales surgen de la postura política de la misma novela americana: el primer arquetipo es la "naturaleza devoradora”, que se encuentra en los orígenes mismos del sujeto híbrido hispanoamericano y en el desarrollo de un sincretismo histórico. Este mismo legado cultural da cuenta del surgimiento del segundo arquetipo, a saber, "el dictador a escala nacional o regional”, puesto que los efectos colaterales de la independencia superpusieron un nuevo despotismo a la antigua dominación, en la mayoría de casos militar o por oligarquías nativas, alcanzando lo denunciado en La vorágine por Rivera con la explotación en las caucherías y la reificación del ser humano: “el hombre civilizado es el pa- ladín de la destrucción”, así como en El otoño del patriarca, cuando se dice que "somos los perros de nosotros mismos”. Entonces, habiéndome servido de Carlos Fuentes, presento al "dictador de novela", no como un simple personaje de ficción, sino, por el contrario, como el símbolo de un ideologema propiamente americano.

La narrativa latinoamericana del dictador conoció en 1946 la que fuera la novela de referencia por muchos años. Hablo de El señor presidente, de Miguel Ángel Asturias². Al lado de ésta, se tienen una serie de novelas que nos permiten afirmar que el tema del dictador no está simplemente en el ambiente literario; es mejor pensar que entre los escritores latinoamericanos existe una preocupación por crear una distancia histórica frente a la realidad delirante del dictador continental, o sea, frente al "único personaje mitológico que ha producido América Latina” ${ }^{3}$. Las no-

Carlos Fuentes, La nueva novela hispanoamericana (México: Joaquín Mortiz, 1972).

Aunque se debe dejar en claro que el siglo XIX conoció novelas que exploran la condición humana en el centro del poder, v. gr., Facundo (1845), de Domingo Faustino Sarmiento.

3 Palabras de García Márquez en las conversaciones con Plinio Apuleyo tituladas El olor de la guayaba (Bogotá: Oveja Negra, 1982, p. 89). A continuación me permito reproducir brevemente esa serie de novelas: La sombra del caudillo, 1928, de Martín Luis Guzmán; La bella y la fiera, 1927, y La mitra en la mano, 1931, de Rufino Blanco Bombona; Fiebre, 1939, y reescrita en 1971, de Miguel Otero Silva; Matan al león, 1970, de Jorge Ibargü entoitia; Oficio de difuntos, 1976, de Arturo Uslar Pietri. Estas novelas utilicemos una metáfora metabólica- todavía se hallan indigestas en su papel de intermediadoras entre el suceso histórico y la conciencia colectiva, o, para decirlo con otra imagen, todavía miran de soslayo al arquetipo del dictador como parte de nuestra identidad. Las novelas de tres cuartos del siglo XX se conforman con sus miradas estereotipadas del despotismo, tanto así que sus héroes se definen de una vez en una frase, pues ideológicamente están culminados desde antes de empezar la novela porque se apoyan y satisfacen en la exterioridad del "se dice que" la figura literaria del dictador debe ser tal o cual cosa. La expresión "se dice” la adopto del ensayo de Jaime Mejía Duque "El otoño del patriarca o la crisis de la desmesura" (1975), en Nueve ensayos literarios (Bogotá: Instituto Colombiano de Cultura, 1986), p. 57-58. Mejía Duque critica fuertemente el Otoño y dice de ella que se consuela con ser una mera referencia externa de la metáfora del poder. Considero que esta crítica cabe para las novelas anotadas, pero en el caso del Otoño se trata más de la iracundia de un lector que esperaba una nueva saga con el lenguaje a la manera de Cien años de soledad. 
velas de tres cuartos del siglo $\mathrm{XX}$, con $E l$ señor presidente a la cabeza, adolecen de distancia histórica para afrontar de cara la posibilidad del dictador como otro ideologema americano. Los héroes déspotas de dichas novelas, de alguna manera, se encuentran limitados, carecen de autonomía, ya que cierta veta sobreviviente del realismo naturalista decimonónico los liga a ser simple encarnación de la maldad consuetudinaria en la historia política de América Latina. Pensando libremente, esa podría ser la razón por la cual García Márquez y Plinio Apuleyo, en El olor de la guayaba, consideran "pésima" la novela de Asturias ${ }^{4}$. Sin todavía haber realizado un juicioso estudio comparativo y de campo, propongo que El gran BurundúBurundá ha muerto (1966) de Jorge Zalamea, fue la narrativa que abrió las puertas a la interioridad del dictador, y El otoño del patriarca (1975), El recurso del método (1974) y Yo, el supremo (1974) -abiertas las puertas- husmearon y esculcaron ese mundo interior del misterio humano de la voluntad de poder.

El paso que se avanza con Zalamea es el de no reducir la problemática a simple pillaje de terratenientes armados, tal como ocurría con la literatura de cow boys, sino de explorar -en su estilo reiterativo, obsesivo y onírico- la experiencia humana del poder y su significado para la condición humana. Posteriormente, con la triada de Roa Bastos, Carpentier y García Márquez, no es tan importante fisgonear la casa y costumbres presidenciales como introducirse en la conciencia del tirano y narrar desde ese centro íntimo del poder. Tanto así que la percepción del lector es la misma de la persona que lo ejerce: "Por eso sean cuales fueren los rasgos particulares que adoptan los diversos dic- tadores, la unidad de los actuales textos narrativos sobre ellos radica en que interrogan directamente el poder omnímodo, ven su pleno funcionamiento, descubren los motivos ignorados de sus acciones, las benéficas y las perversas, diseñan los mecanismo de su terca y en apariencia ilógica continuidad histórica”.

\section{Presentación de El otoño del patriarca}

A continuación se escoge la novela El otoño del patriarca, de García Márquez, para analizar el simbolismo ideológico que encarnan sus personajes, sus relaciones (i. e., edipos) y hasta sus lugares (i. e., la casa presidencial). Iniciamos con una presentación general de la novela diciendo que ella es una obra concentrada en su héroe y pretende hacerse a su monólogo interior desde afuera; la múltiple focalización según la mirada de un narrador colectivo es como poner en boca del "pueblo" la conciencia interior del totalitarismo. El tiempo cíclico y la constante repetición buscan reproducir la sensación de inacabamiento, de eternidad del poder absoluto, a la vez que a cada regreso de la espiral permanece el dictador (como si el despotismo se sucediera a sí mismo), mientras las generaciones humanas del pueblo se relegan, sucesivamente, las unas a las otras, su puesto en la historia, pero carentes de memoria política. No obstante, considero que esta falta de memoria histórica se subsana ante la muerte del déspota y se inicia el ejercicio de hacer un recuento del pasado, es decir, se realiza el ejercicio de hacer conciencia, de tomar distancia histórica, y ello lo hace justamente esa primera persona del plural que narra, a saber, "la voz colectiva de múltiples rostros

Plinio Apuleyo, El olor de la guayaba (Bogotá: Oveja Negra, 1982), p. 85.

5 Ángel Rama, Los dictadores latinoamericanos (México: F.C.E., 1976), p. 16. 
particulares”. La última generación tiene la posición privilegiada de marcar distanciamiento, porque éste se alcanza exclusivamente sobre el pasado, ya que sobre el presente resulta casi imposible.

La imagen senil del Patriarca es el dictamen que hace el autor a las sociedades autoritarias: las condena a un fin de miseria y proclama la venida del "tercer testamento" o fin de la cristiandad, que corresponde al surgimiento definitivo de la sociedad madura civil. Ésta queda representada en la voz de la primera persona del plural, la cual -ante el fin del despotismo- pasará de ser objeto del poder a ser sujeto del mismo y en este sentido se alcanzará una mayoría de edad:

Al resolver la dialéctica de la focalización por la dominación de la perspectiva del Nosotros, la narración filia su axiología en ideologemas de raíz existencial y empirista. Sólo muere de veras el Patriarca, es decir, el que no acepta la finitud; el Nosotros, por la misma razón, queda dueño de la vida ${ }^{6}$.

Por lo mismo, el acontecimiento primordial en el Otoño es la muerte del Patriarca. Los demás sucesos surgen como pequeñas piezas en el recuerdo o flashbacks del personaje-narrador multívoco; en otra palabras, los otros sucesos son piezas menores donde se escenifica la experiencia del poder. El acontecimiento capital es la muerte grande, acción con la cual se inicia la novela sin la previa presentación de personajes, ni de narrador, ni de espacio-tiempo determinados; se trata más bien de la presentación de la acción por lo que vale en sí misma, a la manera de una representación. Más adelante el lector comprenderá la importancia y el an- helo de dicho acontecimiento para un personaje inasible que denominaremos "pueblo" porque tiene una voz colectiva y múltiples rostros particulares. De manera que la narración de este acontecimiento será la percepción caleidoscópica de la psiquis de múltiples personajes-narradores que son subsumidos por la conciencia colectiva del “pueblo”. Dicho de otro modo, el acontecimiento capital es la acción cero que indica la ruptura: "el despertar de un letargo de siglos” y también el inicio de una novísima época. El nuevo testamento está marcado por el nacimiento de Jesús, pues bien, el post-novo testamento está determinado por la muerte del Patriarca: “aun los más incrédulos estábamos pendientes de aquella muerte descomunal que había de destruir los principios de la cristiandad e implantar los orígenes del tercer testamento"7

El acontecimiento capital es el último en la cronología lineal, pero de esto no sabe nada el lector. Él tiene que ir descubriéndolo porque fue abandonado in media res ab initio, tanto así que no se dice de quién es la muerte (aunque es fácilmente intuible). Por decirlo de alguna manera, la novela comienza sin “intrusión del autor” y procura mantenerse así por mucho tiempo. Dato relevante es que la novela inicia con ese acontecimiento, igual cada capítulo, y se desenlaza en el mismo acontecimiento; en consecuencia, es una novela de héroe muerto porque en realidad sus acciones y pensamientos son lo que se conserva en la memoria de ese narrador colectivo multívoco. Es decir, el Otoño no es una mera reconstrucción de la vida del Patriarca, es una revisión desde el mismo presente y es una evaluación indirecta del estado de cosas posterior a la muerte del héroe. Postulamos

6 Lida Aronne-Amestoy, “El mito contra el mito: Narración e ideografía en El otoño del patriarca”, Revista Iberoamericana 52.135-136 (1986), p. 526.

7 Gabriel García Márquez, El otoño del patriarca (Bogotá: Círculo de Lectores, 1975), p. 77. 
-sin mayor preocupación de equívoco- que el esquema del acontecimiento subsume a los personajes. Ángel Rama explica la constante referencia a este hecho como la elaboración artística del tiempo cíclico, el cual está destinado a figurar la "percepción ingenua y popular de la dictadura”; además -agregoindica el ansia porque termine, pero un ansia atada de manos que no puede acelerar el término. Consiste en ser un pueblo al que exclusivamente le queda esperar anhelante y paciente esa muerte de podrida grandeza, para que ahora sí surja un nuevo orden. Recuérdese que cuando se llevaron el mar, el Patriarca promovió una convulsión nacional a la que nadie secundó, ni por la buena razón ni por la fuerza: "con tal de que pase algo aunque se lleven el mar, qué carajo, aunque se lleven la patria entera con su dragón”. . Con tal de romper con el letargo de siglos, no importa sacrificar el mar ni que se lleven al patriarca-dragón, o la Patria misma, pues el gran relato patriótico ya no tiene recepción. Ha llegado la hora del tercer testamento, esto es, el surgimiento de la sociedad civil. No obstante, Rubén Jaramillo Vélez nos advierte que el proyecto de una sociedad civil está condenado al naufragio por razones de sincretismo histórico tales como que "la ciencia llegó a Colombia por revelación”, contrasentido que sólo es posible en tierras de exuberancia real maravillosa. En esta misma perspectiva, García Márquez deja escapar su aliento disfórico acerca del post-novo testamento: el dictador de novela lúcidamente advierte que después de su muerte todo volverá atrás y retornará la misma rapiña de siempre:

Mientras tanto, en el salón del consejo de gobierno invocábamos la unión de to- dos contra el despotismo de siglos para repartirse por partes iguales el botín de su poder, pues todos habían vuelto al conjuro de la noticia sigilosa pero incontenible de su muerte, habían vuelto los liberales y los conservadores reconciliados al rescoldo de tantos años de ambiciones postergadas $(\ldots)^{10}$.

Este es el único momento de la novela donde se dice realmente qué destino se depara la sociedad civil a sí misma, después de la tan esperada muerte del señor de la hacienda. Un ejemplo citado por Rubén Jaramillo es el de los convencionalistas de Rionegro, quienes "desearon terminar la supremacía de los grandes caudillos y lo que obtuvieron fue fomentar la de los pequeños sátrapas y gamonales de los Estados, más crueles, más bastardos y menos inteligentes que los otros”. Esta es una cita de Liévano Aguirre en su biografía de Rafael Núñez, la cual continúa: “quisieron imponer en el país un régimen civilista y republicano, y lo lanzaron en medio del más oscuro y atrasado de los feudalismos, como fue la época federal colombiana" ${ }^{11}$.

\section{La ley de alcoba detrás del poder}

Inicialmente emplearemos la metáfora del sistema solar para explicar el funcionamiento de los personajes en el Otoño. El Patriarca es el astro rey y a su alrededor giran los demás personajes cual astros menores, con excepción tal vez de Bendición Alvarado, su madre, quien hace las veces de estrella tutelar a lo largo de toda la obra. Claro que se tiene otro personaje supremamente importante, el cual presta su mirada al lector y a tra-

\footnotetext{
Rama, Los dictadores..., p. 55.

García Márquez, El otoño..., p. 227.

García Márquez, El otoño..., p. 155.

Rubén Jaramillo Vélez, Colombia: La modernidad postergada (Bogotá: Temis, 1998), p. 33.
} 
vés de él se da cuenta de la historia; me refiero al narrador colectivo.

Bendición Alvarado, la madre del Patriarca, perfectamente puede ser abordada desde una perspectiva psicoanalítica y descubrir el Edipo irresoluto del Patriarca. Si vamos a hablar de un Edipo mal resuelto, se debe hacer desde su estructura básica, a saber, la relación afectiva madre-hijo que determinará las futuras relaciones sentimentales del hijo con otras mujeres. El Patriarca, al ser hijo único de madre soltera, es alguien que tiene vía libre para acceder a la madre, es decir, no requiere de matar a su padre. La ley de prohibición encarnada en el padre no hace mella en él; sin embargo, no debe decirse como lo hace Fernando Cruz Kronfly- que "el patriarca es un hombre sin ley, que no advino al orden de lo simbólico” porque no contó con la interposición de la figura paterna ${ }^{12}$, pues ante la ausencia del padre, la sociedad asume la prohibición, es decir, la ley que inicialmente correspondía al padre ahora queda representada en la sociedad. Es muy cierto que la figura del Patriarca resulta ambigua, pues es a un mismo tiempo niño y anciano, algo así como un infante senil que en todo momento depende de la autoridad materna. Es más, después de la muerte de su madre, él sigue pidiéndole consejo, refugiándose bajo su tutela, e intenta por ello su canonización. Aquí no nos interesa si en efecto la desea sexualmente o no, es más importante hacer emerger el sentido de que debido a esa estructura afectiva el Patriarca nunca conoció el amor adulto, es decir, quedó impedido para amar como hombre, y su amor dependiente siempre fue infantil: recuérdese el miedo profundo que le producen las relaciones sexuales en las que se encuentra comprometido afectivamente (para este caso no cuentan los amores por asalto con su servi- dumbre), v. gr., su primer encuentro sexual, en el río, con la prostituta del pelotón; la autoprohibición que se impuso de Leticia Nazareno viéndola desnuda por dos años, $y$, finalmente, sus defecaciones después de hacerle el amor.

También se debe anotar que el Patriarca guardó con sumo celo fidelidad a su madre del alma; incluso, cuando aparece su primer amor, Manuela Sánchez, éste nunca llega a materializarse. No sabemos bajo qué represiones inconscientes se obstaculiza su concreción, pero lo cierto es que el máximo acercamiento (aprobado por la prohibición materna) fue un leve contacto de manos en la noche del cometa. El patriarca se casa y reconoce a Emanuel como su único hijo legítimo, sólo después del fallecimiento de su madre. Sin embargo, es igualmente significativo el hecho de que al cabo de un tiempo de la desaparición trágica de Leticia y su hijo, él los olvide; igual sucede con la colegiala hacia el final de su otoño; lo que nunca ocurre con el recuerdo de Bendición.

Si sostenemos que la significación profunda de nuestra novela es la condición humana del hombre que posee un poder absoluto y que termina siendo poseído por éste y abandonado por el resto de los hombres, coherentemente debemos hacer emerger el sentido especial de que "el principio de placer gobierna absolutamente la voluntad de poder”. El impulso dionisiaco se impone sobre el deber ser apolíneo; v. gr., la ingerencia de la voluntad de poder en el orden de la naturaleza está motivada por el amor: el Patriarca ordena un eclipse para Manuela Sánchez. De otro lado, la dictadura no es un derivado lógico y necesario de tal o cual crisis sociopolítica, al contrario, el despotismo surge como una verdadera condición humana una vez que el

12 Cf. Fernando Cruz Kronfly, “Acerca de El otoño del patriarca”, Poligramas 1 (1978), p. 144. 
poder posee al hombre. Los gobiernos totalitaristas no son exclusivos de los militares elevados al máximo poder; también los civiles pueden cumplir a cabalidad su papel de déspotas, nada más basta con la obnubilación del poder absoluto. Leticia Nazareno, por antonomasia, es una encarnación de esta condición; una mujer educada en el monasterio, que enseñó a amar al Patriarca, quien siendo primera dama de la nación cometerá los más grandes desmanes de autoridad, propios de los sátrapas. La pregunta que surge es: ¿rrealmente el proceso de civilización, la racionalidad y la confianza del hombre en sí mismo son suficientes para domesticar sus pulsiones salvajes más instintivas? Pensemos en la desilusión frente al poema de Schiller en la novena sinfonía de Ludwig van Beethoven, en Los pasos perdidos.

Señalo esto de los sátrapas civiles para indicar de nuevo la pregunta: ¿hay algo oculto en el hombre que éste, ya sea por represión psicológica o ya sea por procesos civilizatorios, se niega a reconocer y que el ejercicio de poder le da vía libre? Los personajes alrededor del Patriarca de una u otra forma son satélites del poder y bañados por este último actúan según su verdadera condición humana; v. gr., José Ignacio Sáenz de la Barra: muy refinado en sus modales, pero con una maldad que al mismo Patriarca asombra y atemoriza; igualmente el compadre Rodrigo de Aguilar: general de la nación, perdió un brazo por salvarle la vida a su compadre, pero ahora quería "el sitio de elegido de Dios que él le había reservado [a nuestro héroe]”"13, etc. Los anteriores ejemplos demuestran que el despotismo no deviene de una falta de educación o ilustración como en el caso del Patriarca, sino que se trata de una maldad ancestral. No sostengo con esto que existe una maldad genética en la humanidad y que necesariamente el hombre está predeterminado a ser Caín. La novela deja en claro que el ejercicio absoluto del poder saca a flote una maldad propia de la humanidad, es decir, que no es exclusiva de un solo hombre sino que es un valor histórico que le pertenece. Cruz Kronfly afirma que es una maldad legendaria que hace parte del listado de anhelos ocultos de todo hombre ${ }^{14}$.

El personaje de Leticia Nazareno es útil para evaluar la copresencia de modernidad y premodernidad en la novela. No podemos decir de nuestro héroe que sea un déspota ilustrado y, por lo tanto, un sujeto moderno; sin embargo, tampoco conviene desconocer su distanciamiento de la creencia religiosa, la cual queda satirizada o banalizada al máximo, a tal punto que él dice creer (por conveniencia) con el fin de obtener la canonización de su madre. Tampoco se puede pasar por alto la expropiación de los bienes eclesiásticos, así como la separación de los poderes del Estado y la Iglesia, lo que sería el mayor índice de actitud moderna. No obstante, con Leticia la nación es regida por una "ley de alcoba", y ella gobierna como si fuera el mismísimo Patriarca, porque en últimas él aprueba las decisiones de su mujer, aunque no las comparta. La ruptura con la Iglesia se hizo insalvable una vez se denegó la santificación de Bendición Alvarado; por eso, cuando su esposa le pide la restitución de los colegios confesionales, la desamortización de los bienes clericales, "él se volteó de cara a la pared dispuesto a renunciar al tormento insaciable de tus amores lentos y abismales antes que dar mi brazo a torcer a favor de los bandoleros de Dios que durante siglos se han alimentado de los hígados de la patria, ni de vainas, decidió" ${ }^{15}$. Esta cita es una radiogra-

3 García Márquez, El otoño ..., p. 113.

4 Cfr. Cruz Kronfly, “Acerca de El otoño...”, p. 140.

15 García Márquez, El otoño ..., p. 162. 
fía del paso de una premodernidad eclesiástica a una modernidad civil, aunque, claro está, las formas se siguen conservando, es decir, hoy se cree en la Patria con el mismo fervor que antes se creyó en Dios. Notamos que el Patriarca no se sostiene radicalmente en su posición, no renuncia al mundo, esto es, no renuncia al tormento insaciable de los amores lentos y abismales de Leticia, y termina por compartir, por consentir, por acomodarse a las situaciones. Finalmente volvieron a abrirse los templo clausurados, se restablecieron las antiguas fiestas de guardar y la modernidad civil fue echada para atrás, pues "fueron abolidas las leyes recientes del matrimonio civil, el divorcio vincular, la educación laica”16. En otras palabras, la modernidad se dejó para después, se postergó su proyecto.

Una prueba de que el paso de la premodernidad a la modernidad es un vaciamiento de contenidos que conservó las formas, la tenemos en el momento en que es posible revertir el proceso, a saber, regresar a Dios al centro de la nación: "los himnos de júbilo de las muchedumbres que antes cantaban para exaltar su gloria [la del Patriarca] ahora cantaban arrodilladas bajo el sol ardiente para celebrar la buena nueva de que habían traído a Dios en un buque mi general, de veras, lo habían traído por orden tuya, Leticia”17. Ella es la potencia oculta del gobierno que estimula el principio de placer que gobierna la voluntad de poder.

\section{El modelo hacendario de administración pública}

Hay una imagen que acompaña constantemente al Patriarca y que en ocasiones hace sus veces; me refiero a las vacas (cuya simbología plena, debo confesarlo, se me escapa todavía). En diversas declaraciones, el autor ha sostenido que la imagen estimulante para escribir el Otoño era un dictador rodeado de vacas; su justificación es que por regla general los dictadores fueron hacendados: “en Latinoamérica los dictadores son vacunos”, afirmó García Márquez ${ }^{18}$. El Patriarca no parece el mandatario de una nación sino de una hacienda; realmente sus órdenes no parecen decidir el horizonte de un pueblo sino, más bien, los destinos de una casa grande. En palabras sencillas y puntillosas, el narrador califica el tipo de mandato del Patriarca con la expresión "sentido de gobierno inmediato”: “no había una contrariedad de la vida cotidiana por insignificante que fuera que no tuviera para él tanta importancia como el más grave de los asuntos de estado”"19. Luego, el paternalismo y la gobernabilidad inmediata son los rasgos fundamentales del arquetipo del dictador latinoamericano, que entre otras cosas es un ideologema de análisis y de identidad profundamente real maravilloso pero de corte disfórico, con el cual se deberían completar los seis discursos ideológicos sobre América propuestos por Irlemar Chiampi ${ }^{20}$. Las figuras históricas más contundentes fueron los

6 García Márquez, El otoño ..., p. 162.

García Márquez, El otoño ..., p. 163.

18 Ernesto González Bermejo, “Ahora 200 años de soledad” [entrevista, 1971], García Márquez habla de García Márquez, de Alfonso Rentaría (Bogotá: Rentaría Editores, 1979), p. 57.

19 García Márquez, El otoño ..., p. 83.

20 En El realismo maravilloso (1976; Caracas: Monte Ávila, 1983), que en el subtítulo contiene toda la búsqueda de identidad de los autores íberoamericanos, a saber, Forma e ideología de la novela hispanoamericana, la autora propone seis ideologemas propiamente americanos: (i) los orígenes cronísticos, (ii) la neoutopía ilustrada, (iii) civilización vs. barbarie, (iv) América: ¿latina o mestiza?, (v) europeísmo vs. indigenismo, y (vi) el mestizaje cultural. 
césares; sin embargo ni éstos ni los dictadores modernos europeos tienen comparación con los nuestros, porque no son realmente exuberantes en su realidad histórica. Me explico: las extravagancias personales de nuestros dictadores, su sentido de gobierno de hacendado, de casa grande, de gobierno inmediato, se suman al absolutismo político precolombino: el imperialismo nativo de Moctezuma fue el que (por efecto reflejo) ayudó a la conquista de Hernán Cortés, pues revisando los anaqueles historiográficos se encuentra que las tribus que colaboraron en la expedición de Cortés fueron las mismas subyugadas por el imperio azteca, las cuales no esperaban una completa liberación pero al menos sí un cambio de mano de mando. Por ende, nuestro héroe no es la personificación de la dictadura en tanto "totalidad", cuando por ésta se entiende un recorte y recomposición azarosa de los fragmentos para formar el nuevo dictador que sería el Patriarca; en otras palabras, el gran aporte de la mayoría de la literatura crítica es afirmar que el Patriarca es la sumatoria de fragmentos de los diversos dictadores latinoamericanos. El problema de ver al dictador de novela como una colcha de retazos es reducir la crítica a encontrar los referentes reales de cada fragmento ${ }^{21}$.

El Patriarca está muy lejos de ser un mosaico inconexo y acumulativo de dictadores. Su función es representar el arquetipo del "mito latinoamericano del dictador" y retomo esta expresión de García Márquez porque es la única forma de explicar una cierta identificación compasiva del lector con el héroe sátrapa. El dictador de novela es un espejo en el que la conciencia colectiva del lector descubre su pasado histórico, es decir, nuestro héroe se constituye en la distancia histórica, en la historia digerida de nuestro pasado cultural: la experiencia humana latinoamericana es elevada a arte en un ejercicio de autorreconocimiento. Por tanto, el dictador de novela no es un hombre en particular ni mucho menos recortes de distintos presidentes; es la figura de una sociedad compleja, contradictoria y ambigua, cuyas pulsiones de placer gobiernan explícita o inconscientemente su principio de realidad.

El palacio presidencial es la simbolización de la Casa Grande, esto es, la nación administrada como una hacienda. La casa grande también es, en primer lugar, un modelo de administración de la nación, y el poder siempre es uno instrumental y de inmediata ejecución. García Márquez satiriza esta administración a través de una casa-presidencialgranja:

Todo aquello no parecía entonces una casa presidencial sino un mercado donde había que abrirse paso por entre ordenanzas descalzos que descargaban burros de hortalizas y huacales de gallinas en los corredores (...) y todo aquello entre el escándalo de los funcionarios vitalicios que encontraban gallinas poniendo en las gavetas de los escritorios, y tráficos de

21 En este inconveniente cae Conrado Zuluaga con su obra Novelas de dictador-dictadores de novela (Bogotá: Carlos Valencia, 1979), donde reduce la problemática a una delirante búsqueda de alusiones a los personajes históricos sin ninguna otra intención que la referencia. El último capítulo de su libro, “América Latina no tiene historia”, por el sólo título despierta un horizonte de expectativas acerca de la ideología americana, pero se Áonforma con decir que los personajes históricos superan en exuberancia a los literarios, es decir, que América Latina no tiene memoria, según la exigencia realista de Zuluaga, porque la literatura se queda corta frente a la realidad mágica americana. Conforme a esto, el libro de Zuluaga resulta significativo a razón de señalar desprevenidamente el carácter real maravilloso de nuestros dictadores, que es el punto de la propiedad sobre el "animal mitológico propiamente latinoamericano". 
putas y soldados en los retretes, y alborotos de pájaros, y peleas de perros callejeros en medio de las audiencias ${ }^{22}$.

El punto final de la crítica satírica llega cuando se pone en cuestión la identificación del poder y la casa grande en medio de ese pandemonio: “aquel palacio de puertas abiertas dentro de cuyo desorden descomunal era imposible establecer dónde estaba el gobierno”. En segundo lugar, la casa grande es un modelo civil de manejo del país que conserva aún la forma de administración eclesial; hablemos pues del "Estado confesional”. La administración de la hacienda devino "modelo social” aceptado rápidamente por toda la nación, y fue el modelo normativo de todas las articulaciones y manifestaciones del poder. Tanto así que el proyecto de una sociedad civil se vería cada vez más retardado al encomendársele a la Iglesia la "socialización cultural del país”: “lo cual garantizó, por generaciones, la reproducción del modelo hacendario de lealtades y de dominación social que la iglesia había adoptado en los siglos coloniales, al servicio de los grandes terratenientes"23.

A partir del modelo social de la hacienda se desprende una actitud feudal premoderna, $i$. e., el Patriarca es el señor y todo el pueblo le debe su favor, puesto que literalmente es el padre de toda la nación. V. gr., cuando un hombre le hizo un atentado, lo mandó a descuartizar y luego lo hizo exhibir a la luz pública, como un acto de escarmiento para todo aquel "que levanta la mano contra su padre"24; asimismo, en otras ocasiones se queja de que no agradecen a la mano que les da de comer. La lealtad la exige el señor a sus siervos en contraprestación a la protección que les brinda; un ejemplo lo tenemos en el caso de los dos mil niños de la lotería: a los catorce comandantes del mando supremo los absolvió de toda culpa, porque su decisión era ignorar el suceso y selló la sesión con la sentencia proteccionista del señor: "yo respondo" 25 . Un ejemplo doblemente significativo es el de la soberbia del señor hacendario que llega incluso a imponérsele a la señoría papal, donde al tiempo se percibe cómo la forma eclesial permanece en la ética civil: “que todo el mundo sepa cómo terminan los forasteros que levantan la mano contra la majestad de la patria”26.

\section{El "pueblo" como personaje y como autogestor de saber narrativo}

Ahora pasamos a otro personaje muy especial que está presente a lo largo de toda la novela en forma casi imperceptible para el lector común. Este efecto se produce porque posee una voz colectiva y múltiples rostros particulares, así que no se puede identificar con alguien en concreto y se dificulta retenerlo en la memoria de personajes. Este es nada menos que la voz del "extenso animal de la ciudad” que comienza a despertar del letargo incalculable del totalitarismo. Tiene la particularidad de ser un personaje-narrador colectivo y anónimo en la mayoría de casos que narra en primera persona del plural, en la persona del nosotros. En razón a esto lo nombramos con el sustantivo colectivo de “pueblo". Con relación a los juegos de lenguaje que legitiman los saberes,

García Márquez, El otoño ..., p. 10.

3 Fernando Guillén Martínez, La Regeneración: Primer Frente Nacional (Bogotá: Carlos Valencia, 1986), p. 17.

24 García Márquez, El otoño ..., p. 112.

García Márquez, El otoño ..., p. 102.

2 García Márquez, El otoño ..., p. 133. 
Lyotard en La condición postmoderna dice que el "pueblo" es el personaje y héroe de las culturas narrativas. Apoyándonos en el deconstruccionismo de Paul K. Feyerabend con respecto a la hegemonía del discurso científico occidental, en un libro suyo como Contra el método, y en relación con Lyotard, tenemos que discurso narrativo popular (en el sentido más etimológico de "en relación al pueblo") no es un lapsus del juego de lenguaje logocéntrico. Es más, un pensador como Hayden White ${ }^{27}$ demostró que los discursos cientificistas, entre ellos el histórico, tienen una estructura discursiva propiamente narrativa. Incluso el pueblo mismo es quien declara la muerte de sus saberes tradicionales impuestos exógenamente:

El saber de los relatos retorna a Occidente para aportar una solución a la legitimación de las nuevas autoridades. Es natural que en una problemática narrativa, esta cuestión espere la respuesta de un héroe: ¿quién tiene derecho a decidir por la sociedad? ¿cuál es el sujeto cuyas prescripciones son normas para aquellos a quienes obligan?

Este modo de interrogar la legitimidad socio-política se combina con la nueva actitud científica: el héroe es el pueblo, el signo de la legitimidad su consenso, su modo de normativación la deliberación ${ }^{28}$.

En nuestra novela, el "pueblo" es quien da cuenta de la muerte grande, es el testigo de su otoño y es quien celebra los nuevos tiempos. El "pueblo" brinda un caleidoscopio de los acontecimientos, y al circular la narración en un sinnúmero de perspectivas, según los diversos personajes, se obliga al lector a elaborar un juego de rompecabezas para recomponer finalmente la pieza total, el mosaico definitivo. En El olor de la guayaba, García Márquez le confiesa a Plinio Apuleyo Mendoza que su punto de partida para escribir es una "imagen visual". Pues bien, el Otoño parte de una imagen, continúa con imágenes y termina remarcando la imagen del otoño. Dichas imágenes son los puntos de vista que ofrece este personaje colectivo en especial. Sobre el particular, Ángel Rama sostiene que el propósito de la novela es el de "conseguir que el lector deambule por el más dificultoso de los laberintos posibles, que ya no será meramente explicado como es habitual en el arte intelectualizado de Borges, sino vivido sensorialmente en la experiencia de lectura" ${ }^{\text {"29 }}$. Nuestro personaje-narrador tiene por función renovar la literatura del dictador y resemantizar la figura del déspota latinoamericano como un arquetipo que se creía agotado por el periodismo, la política y la literatura militante. La nueva narrativa ha servido de intermediación para cobrar distancia histórica y para ayudar a digerir culturalmente y como identidad americana dicho arquetipo.

Por otro lado, este personaje representa la sociedad civil que ha estado expectante, $y$ celebra la muerte grande $\mathrm{y}$, sobre todo, los nuevos tiempos. En este estudio, sostenemos que los valores que son criticados en la novela son los de una vivencia egoísta y desoladora del poder, lo que conduce al totalitarismo; por su parte, el nuevo valor que se ofrece es el de una renaciente sociedad civil, la que tal vez sea una segunda oportunidad, porque, al fin y al cabo, el quid de la Ilustración es la experiencia de la autonomía.

27 Hayden White, Metahistoria: La imaginación histórica en la Europa del siglo XIX (México: F.C.E., 1992), p. 10.

28 Jean François Lyotard, La condición postmoderna (Madrid: Cátedra, 2000), p. 60.

29 Rama, Los dictadores..., p. 55. 
Por su parte, García Márquez expresa una versión disfórica del post-novo testamento, pero en principio es la primera y única salida de la minoría de edad. Cosa distinta es que -como lo pensó Sartre-, si no hemos tenido una experiencia de la libertad, ¿cómo se pretende que nos sepamos desenvolver correctamente en ella? Es decir, después de la muerte de Dios alguien tiene que ocupar su cátedra y el hombre es un inexperto en este puesto; pero peor que esto es pedir su regreso. Mejor dicho: no puede haber excusa para evadir la responsabilidad y en algún momento se tiene que dar el primer paso, $\mathrm{y}$ el final de la cristiandad-totalitarismo es un buen principio:

Repetían de memoria abajo la opresión, gritaban, muera el tirano, y hasta los centinelas de la casa presidencial leían en voz alta por los corredores la unión de todos sin distinción de clases contra el despotismo de siglos, la reconciliación patriótica contra la corrupción y la arrogancia de los militares, no más sangre, gritaban, no más pillaje, el país entero despertaba del sopor milenario $(. . .)^{30}$.

El pueblo que inicialmente se identifica con el arquetipo del Patriarca es el mismo que en el desenlace cancela la realidad ilusoria del héroe. El pueblo paradójicamente se reconoce como resultado y generador del despotismo, pues a pesar de desear profundamente su muerte también padece de incertidumbre frente a una minoría de edad. Para alcanzarse la realización de una sociedad civil es conditio sine qua non la muerte del tutor autoritario. De todas formas "habíamos terminado por no entender cómo seríamos sin él, qué sería de nuestras vidas después de él”31. Posteriormente la misma conciencia sanciona satíricamente el otoño definitivo en tanto pérdida evasiva de su señor, quien fue:

(...) un tirano de burlas que nunca supo dónde estaba el revés y dónde estaba el derecho de esta vida que amábamos con una pasión insaciable que usted no se atrevió ni siquiera a imaginar por miedo de saber lo que nosotros sabíamos de sobra, que era ardua y efímera pero que no había otra, general, porque nosotros sabíamos quiénes éramos mientras él se quedó sin saberlo para siempre ${ }^{32}$.

\section{Conclusión: la crítica satírica}

Es común encontrar que el Patriarca sea interpretado como una parodia, una hipérbole macabra, un títere, una ironía o una carnavalización del poder, entre otras tantas opciones. En principio esto es cierto, y a primera vista todas las anteriores resultan sinónimos dentro de la interpretación de la novela; por nuestra parte, incluiremos una categoría abarcante con la cual aportar una herramienta de análisis, no tan nueva pero sí muy pertinente: me refiero a la sátira. De una u otra manera la sátira se relaciona con los calificativos anteriores y los que se reúnen en la amplia pero imprecisa categoría de caricatura; el plus de nuestra noción lo fundamentamos científicamente en el crítico Matthew Hodgart y su libro titulado precisamente Sátira, puesto que ésta "no sólo es la forma más corriente de la literatura política, sino que, en cuanto pretende influir en la conducta pública, es la parte más política de la literatura”33.

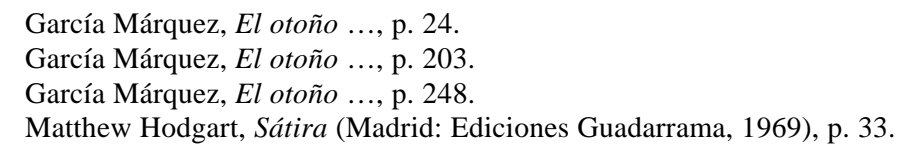


Así las cosas, la sátira será una mirada o forma política de considerar el mundo, tal vez no la más noble ni la más excelsa, pero sí una que efectivamente rompe con todo oficialismo, $y$, en este sentido, resulta muy carnavalesca. La enseñanza de la obra de Hodgart es que la sátira obliga $a b$ initio a una postura crítica y hostil, de incomodidad e insatisfacción ante el vicio y la estupidez del hombre; estas últimas llegan a integrarse hasta la médula, tanto que incluso caracterizarían una condición humana de cierto grupo cultural. El escritor satírico ataca con mayor saña a los gobiernos despóticos por ser la mayor expresión de la corrupción política. El ejercicio que quedaría pendiente es realizar una revisión de la novela del dictador hispanoamericano y comprobar o refutar si la sátira figura como ingrediente esencial en la evaluación de esos escritores.

Según el aporte teórico de Matthew Hodgart, la sátira se sitúa por encima del personaje satirizado, es decir, efectúa una especie de “exaltación” de la ruindad y el deterioro moral del sujeto criticado. La estrategia más recurrente es la reducción al absurdo, que consiste en desvalorizar a la víctima mediante la degradación de su dignidad o valor simbólico representativo. Esto es el equivalente de la desmitificación del déspota en nuestra novela: "La finalidad del satírico consiste frecuentemente en desinflar a los falsos héroes, los impostores y los charlatanes, que pretenden un respeto que no les es debido" ${ }^{34}$. Otro rasgo de la crítica del escritor satírico estriba en denigrar de las instituciones oficiales, que en el caso de la novela del dictador se traduce en una punzante ironía contra la Iglesia. Encontramos en esa perspectiva un fragmento ideológico de García Márquez en el que el Patriarca le contesta al nuncio: "para qué me quiere convertido si de todos modos hago lo que ustedes quieren" 35 .

Es difícil entender el ateísmo de nuestro héroe, el que -recordemos- está acompañado de la expropiación de los bienes de la Iglesia, cuando en la novela se insiste reiteradamente en la imagen del déspota como un dios. V. gr., su madre lo concibió sola, él resucita a los tres días, es el enmendador de los errores de Dios y su voluntad es divina: "son las ocho, carajo, las ocho, dije, orden de Dios"36. Una explicación de corte satírico la encontramos en Seymour Menton, quien al año siguiente de la publicación de la novela, sostuvo que "la autoidentificación del patriarca con Dios la utiliza García Márquez para burlarse tanto de la fe religiosa del pueblo como de la jerarquía eclesiástica" ${ }^{37}$. Palabras que ratifican la intención desmitificadora del escritor satírico; incluso su postura satírica va más allá y en su evaluación nos dice que el déspota es la versión civil de la anterior forma inquisitorial, puesto que el dictador ha terminado por suplantar a la Iglesia: en el Otoño la predominancia del dictador es más vasta, cercana y convincente que la percibida por la religión -salvo el caso de la adoración del pueblo por el cadáver sacrosanto de Bendición Alvarado, que en definitiva resultó ser un simulacro.

En conclusión, la crítica de García Márquez es una apuesta por la sátira hiriente y consciente que despoja a la institución religiosa caduca de su función representativa del po-

\footnotetext{
Hodgart, Sátira ..., p. 28.

García Márquez, El otoño ..., p. 21.

García Márquez, El otoño ..., p. 66.

37 Citado por Juan Antonio Ramos en su tesis doctoral "Hacia El otoño del patriarca: la novela del dictador en Hispanoamérica”, University of Pennsylvania, 1979 (Michigan, EEUU: University Microfilms International, 1985), p. 133.
} 
der divino, conservando sus moldes como un caparazón vacío que pasa a ser ocupado por el totalitarismo. Tanto es así que el pueblo cree en la figura del Patriarca como antes creyó en Dios.

\section{Bibliografía}

Carpentier, Alejo. Los pasos perdidos. Barcelona: RBA, 1993.

Cros, Edmond. El sujeto cultural. Medellín: EAFIT, 2003.

Cruz Kronfly, Fernando. La tierra que atardece. Bogotá: Planeta, 1998.

García Usta, Jorge. Cómo aprendió a escribir García Márquez. Medellín: Escribir Asesores, 1995.

Girard, René. Mentira romántica y verdad novelesca. Barcelona: Anagrama, 1985.

Goldmann, Lucien. Para una sociología de la novela. Madrid: Ayuso, 1975.

Sociología de la creación literaria. Buenos Aires: Nueva Visión, 1971.

Gullón, Ricardo. García Márquez o el olvidado arte de contar. Madrid: Taurus, 1970.

Iriarte, Alfredo. Bestiario tropical. Bogotá: Ediciones Gamma, 1987.
Kulin, Katalin. Creación mítica en la obra de García Márquez.. Budapest: Akadémiai Kaído, 1980.

Mutis, Álvaro. “La desesperanza” (1965). Poesía y prosa. Bogotá: Editorial Andes/ Instituto Colombiano de Cultura, 1989.

Palencia-Roth, Michael. Gabriel García Márquez: la línea, el círculo y las metamorfosis del mito. Madrid: Gredos, 1983.

Pouliquen, Hélène. Para una poética sociológica. Cuadernos de Trabajo, Facultad de Ciencias Humanas, No. 12. Bogotá: Universidad Nacional de Colombia, 1995.

Rama, Ángel. La crítica de la cultura en América Latina. Caracas: Ayacucho, 1985.

La narrativa de Gabriel García Márquez: edificación de un arte nacional y popular. Bogotá: Colcultura, 1991.

Transculturación narrativa en América Latina. México: Siglo XXI, 1985.

Varios autores. Recopilación de textos sobre Gabriel García Márquez. Serie Valoración Múltiple del Centro de Investigaciones Literarias. La Habana: Casa de las Américas, 1969. 